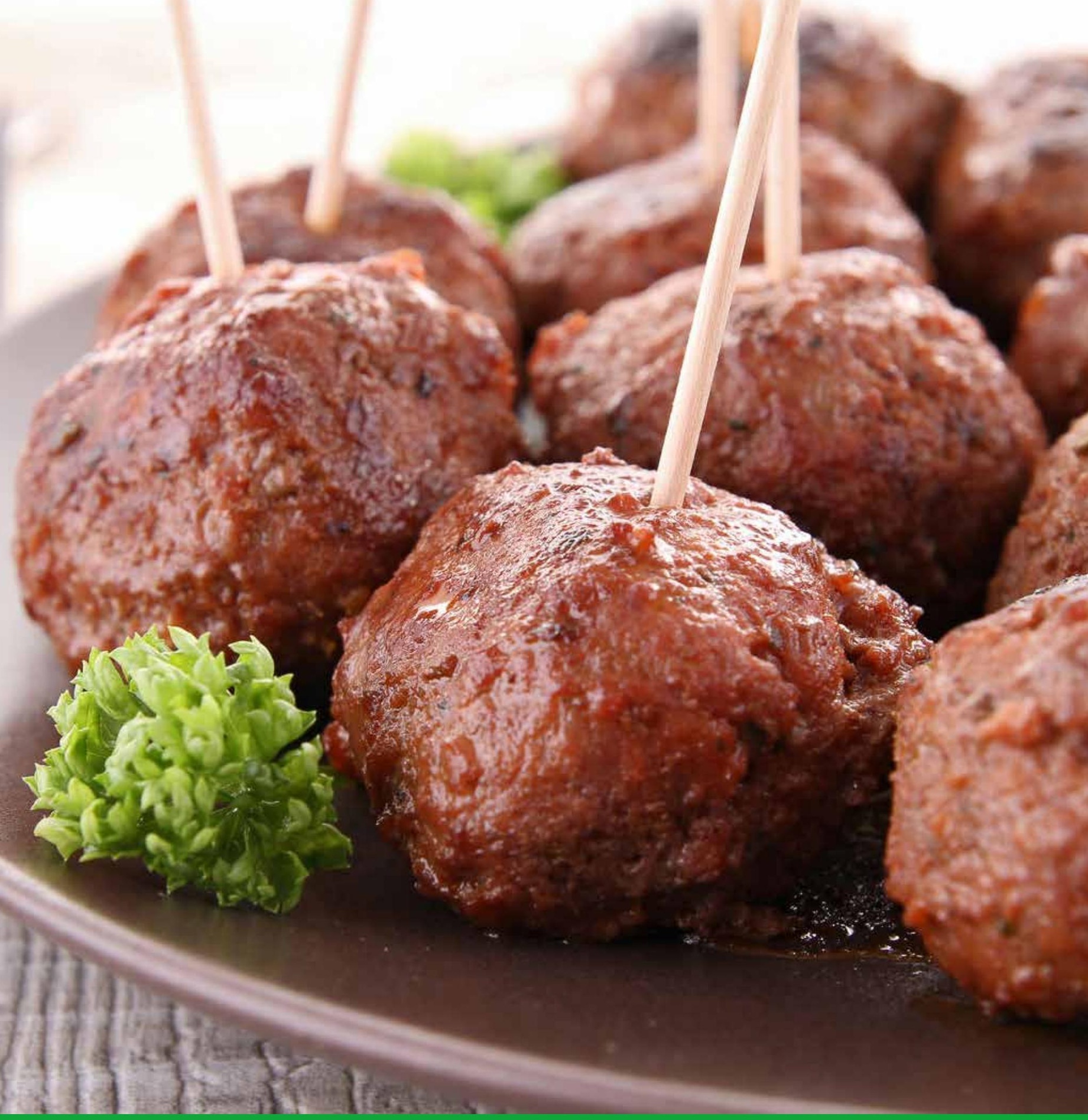

\title{
Vleesconsumptie per hoofd van de bevolking in Nederland, 2005-2019
}

Hans Dagevos, David Verhoog, Peter van Horne en Robert Hoste

WAGENINGEN

UNIVERSITY \& RESEARCH 



\section{Vleesconsumptie per hoofd van de bevolking in Nederland, 2005-2019}

Hans Dagevos, David Verhoog, Peter van Horne en Robert Hoste

Dit onderzoek is uitgevoerd door Wageningen Economic Research in opdracht van en gefinancierd door Wakker Dier.

Wageningen Economic Research

Wageningen, september 2020

NOTA

2020-078 
Hans Dagevos, David Verhoog, Peter van Horne en Robert Hoste, 2020. Vleesconsumptie per hoofd van de bevolking in Nederland, 2005-2019. Wageningen, Wageningen Economic Research, Nota 2020-078. 14 blz.; 2 fig.; 2 tab.; 6 ref.

Deze nota geeft een overzicht van de vleesconsumptie per hoofd van de bevolking in Nederland in de jaren 2005-2019. Het totale verbruik van vlees en vleeswaren per hoofd van de bevolking in Nederland ligt in 2019 op 77,8 kg (op basis van karkasgewicht). Dit is een stijging van 0,6 kg ten opzichte van 2018. De toename komt voor het overgrote deel $(0,4 \mathrm{~kg})$ voor rekening van een stijging in het verbruik van pluimveevlees. Na de stijging met ruim een halve kilo tussen 2017 en 2018 is er tussen 2018 en 2019 eenzelfde toename.

Dit rapport is gratis te downloaden op https://doi.org/10.18174/531409 of op www. wur. nl/economicresearch (onder Wageningen Economic Research publicaties).

(C) 2020 Wageningen Economic Research

Postbus 29703, 2502 LS Den Haag, T 07033583 30, E communications.ssg@wur.nl, www.wur.nl/economic-research. Wageningen Economic Research is onderdeel van Wageningen University \& Research.

\section{(cc) BY-NC}

Dit werk valt onder een Creative Commons Naamsvermelding-Niet Commercieel 4.0 Internationaallicentie.

(C) Wageningen Economic Research, onderdeel van Stichting Wageningen Research, 2020

De gebruiker mag het werk kopiëren, verspreiden en doorgeven en afgeleide werken maken. Materiaal van derden waarvan in het werk gebruik is gemaakt en waarop intellectuele eigendomsrechten berusten, mogen niet zonder voorafgaande toestemming van derden gebruikt worden. De gebruiker dient bij het werk de door de maker of de licentiegever aangegeven naam te vermelden, maar niet zodanig dat de indruk gewekt wordt dat zij daarmee instemmen met het werk van de gebruiker of het gebruik van het werk. De gebruiker mag het werk niet voor commerciële doeleinden gebruiken.

Wageningen Economic Research aanvaardt geen aansprakelijkheid voor eventuele schade voortvloeiend uit het gebruik van de resultaten van dit onderzoek of de toepassing van de adviezen.

Wageningen Economic Research is ISO 9001:2015 gecertificeerd.

Wageningen Economic Research Nota 2020-078 | Projectcode 2282100389

Foto omslag: Shutterstock 


\section{Inhoud}





\section{$1 \quad$ Inleiding}

Wakker Dier is geïnteresseerd in de omvang van de vleesconsumptie per hoofd van de bevolking in Nederland. Wakker Dier heeft Wageningen Economic Research opnieuw benaderd om de vleesconsumptie per hoofd van de bevolking in Nederland te berekenen. Wageningen Economic Research heeft dit in 2015 voor het eerst gedaan (Verhoog et al., 2015). Ook heeft Wakker Dier gevraagd de huidige vleesconsumptie per hoofd van de bevolking in Nederland te vergelijken met eerdere jaren, zodat trends in de vleesconsumptie zichtbaar worden.

Deze nota geeft in hoofdstuk 3 een overzicht van het vleesverbruik per hoofd van de bevolking in Nederland in de jaren 2005-2019 en maakt daarbij onderscheid naar de volgende vleessoorten: rundvlees, varkensvlees, schapen- en geitenvlees, paardenvlees, pluimveevlees en totaal vlees.

In hoofdstuk 4 zetten we de actuele vleesconsumptie in Nederland af tegen de hoeveelheden zoals die worden aanbevolen door respectievelijk de Schijf van Vijf en de EAT-Lancet Commissie.

Traditiegetrouw geeft het afsluitende hoofdstuk enige achtergrond bij de jongste cijfers. Dit jaar is ervoor gekozen kort in te gaan op twee punten die in de twee voorgaande edities van deze nota zijn gemaakt. In de 2018-nota is met het oog op de vleesconsumptie in Nederland verwezen naar buitenhuishoudelijke consumptie. De nota van vorig jaar wijst op de bijdrage van buitenlandse toeristen aan de hoeveelheid vlees die binnen onze landsgrenzen wordt gegeten. 


\section{Berekeningswijze}

Wageningen Economic Research gebruikt de systematiek van de voorzieningsbalansen om het vleesverbruik per hoofd van de bevolking te bepalen. Deze methodiek sluit aan bij de methode zoals die in het verleden tot 2012 is toegepast door PVE. Daarmee wordt de vleesconsumptie zo goed mogelijk benaderd. De methodiek komt erop neer dat het verbruik in een bepaald jaar wordt afgeleid van het aantal slachtingen van dieren, de invoer en uitvoer van vlees zoals die in de CBS-statistieken te vinden zijn en de voorraadmutaties. Bij deze mutaties gaat het om vlees dat wordt opgeslagen in bijvoorbeeld een koelhuis om in het jaar daarop te worden geconsumeerd (voorraad wordt groter en verbruik dit jaar kleiner) of om vlees dat juist uit het koelhuis wordt gehaald om nu te worden geconsumeerd (voorraad wordt kleiner en verbruik groter). In de CBS-handelsstatistieken valt vlees uiteen in een groot aantal diersoorten en onderdelen van dieren, zoals schouders, achterdelen en ribstukken. Verder worden allerlei bewerkte vormen van vlees geregistreerd, zoals vers vlees, bevroren vlees, gedroogd vlees, gezouten vlees, hammen en vleeswaren. In totaal zijn meer dan 500 producten meegenomen, tot op een vrij gedetailleerd niveau. Producten waar vlees in zit verwerkt, zoals lasagne en kippensoep, zijn in deze berekeningen buiten beschouwing gelaten. Dat komt omdat het moeilijk is om op nationaal niveau te bepalen hoeveel vlees er in deze producten - die van verschillende fabrikanten afkomstig zijn - zit.

Voor voorraadmutaties van vlees bestaat geen bron die we kunnen gebruiken. Dat komt bij de berekeningen van voorzieningsbalansen voor andere producten dan vlees ook regelmatig voor; in zulke gevallen is het gebruikelijk dat de opstellers van de balans zelf een aanname voor de voorraadmutatie maken. In het geval van de voorzieningsbalans voor vlees is dat als volgt gedaan: we veronderstellen dat het verbruik bestaat uit directe consumptie en het aanleggen van een voorraad. Voor het berekende verbruik is op basis van expertise een inschatting gemaakt van de voorraadmutaties, waarbij ook rekening is gehouden met een inschatting voor buitenshuisconsumptie en met de jaarlijkse mutatie van de aankopen door consumenten per vleessoort op basis van GfKdata. Met deze data kan een betere inschatting gemaakt worden van de verhouding tussen de directe consumptie en het deel bestemd voor de voorraad in het berekende verbruik. GfK-data zijn gebaseerd op de aankopen van levensmiddelen bij de detailhandel in Nederland door een panel van 6.000 personen.

Verder zijn de berekeningen alleen gericht op menselijke consumptie van vlees en vleesproducten. De consumptie van slachtbijproducten door (huis)dieren (zoals honden, katten, nertsen) is buiten beschouwing gelaten.

De berekeningen van de vleesconsumptie gaan over vlees en vleesproducten, zonder de eetbare slachtbijproducten zoals lever en vetten. Deze werkwijze sluit aan bij de internationaal gangbare aanpak. 


\section{$3 \quad$ Vleesverbruik per hoofd van de bevolking}

Het totale verbruik van vlees en vleeswaren (op basis van karkasgewicht) per hoofd van de bevolking in Nederland beloopt in 2019 77,8 kg (tabel 3.1). Deze hoeveelheid van bijna $78 \mathrm{~kg}$ ligt ruim een halve kilo boven het verbruik in 2018. Deze stijging in de vleesverbruikscijfers tussen 2018 en 2019 is gelijk aan de toename tussen de voorgaande jaren 2017-2018. Evenals in laatstgenoemde jaren geldt voor de jaren 2018-2019 dat voor de tweede achtereenvolgende keer het merendeel van de toename in het verbruik voor rekening komt van pluimveevlees (kip en gevogelte). Varkensvlees is, eveneens als eerder, voor een klein deel verantwoordelijk voor de stijgende cijfers. De tendens in eerdere jaren dat de cijfers gelijk blijven voor de overige vleessoorten die zijn onderscheiden, zet ook door. De cijfers voor rund-, schapen- en geiten- en paardenvlees zijn in 2019 niet veranderd ten opzichte van de 2018-cijfers. Dit is een constatering die ook in voorgaande jaren kon worden gedaan.

De 2019-cijfers betekenen dat er na vorig jaar opnieuw een oplopende trend is. Een meerjarige stijging hebben we voor het laatst gezien vóór de jaren tien: tussen 2005-2009. De jaren tien begonnen in de eerste helft (2010-2015) met een daling, waarna stabiele cijfers waren te noteren voor de jaren 2016 en 2017. De 2018-cijfers lieten voor het eerst weer een iets stijgend vleesverbruik in Nederland zien. De cijfers voor 2019 herhalen dit resultaat. Een hoeveelheid van 77,8 kg betekent een terugkeer naar het vleesverbruikscijfer van 2007. De geboekte cijfers voor de afgelopen 3 jaar reproduceren die van 12 jaar terug: een cyclus lijkt zich te herhalen door de (vrijwel) gelijke cijfers voor respectievelijk 2005 en 2017 (76,7 kg), 2006 en 2018 (77,1kg) en 2007 en 2019 (77,8 kg).

Tabel 3.1 Vleesverbruik a) per hoofd van de bevolking in Nederland, 2005-2019 (kg)

\begin{tabular}{lrrrrrrrrrrrrrrrr} 
& 2005 & 2006 & 2007 & 2008 & 2009 & 2010 & 2011 & 2012 & 2013 & 2014 & 2015 & 2016 & 2017 & 2018 & 2019 \\
\hline Varkensvlees & 37,2 & 37,4 & 37,6 & 37,8 & 37,7 & 37,7 & 37,7 & 37,3 & 37,1 & 36,7 & 36,6 & 36,5 & 36,5 & 36,6 & 36,7 \\
\hline Pluimveevlees & 20,7 & 20,8 & 21,5 & 21,6 & 22,5 & 22,5 & 22,1 & 22,0 & 22,3 & 22,5 & 22,1 & 22,2 & 22,1 & 22,5 & 22,9 \\
\hline Rundvlees & 15,9 & 16,1 & 16,1 & 16,1 & 16,3 & 16,2 & 15,9 & 15,7 & 15,7 & 15,5 & 15,4 & 15,4 & 15,4 & 15,5 & 15,5 \\
\hline Kalfsvlees & 1,3 & 1,3 & 1,3 & 1,4 & 1,4 & 1,3 & 1,3 & 1,3 & 1,3 & 1,3 & 1,3 & 1,3 & 1,3 & 1,3 & 1,3 \\
\hline $\begin{array}{l}\text { Schapen- en } \\
\text { geitenvlees }\end{array}$ & 1,0 & 1,0 & 1,0 & 1,1 & 1,1 & 1,1 & 1,1 & 1,1 & 1,2 & 1,2 & 1,2 & 1,2 & 1,2 & 1,2 & 1,2 \\
\hline Paardenvlees & 0,6 & 0,5 & 0,2 & 0,1 & 0,1 & 0,1 & 0,1 & 0,1 & 0,1 & 0,1 & 0,1 & 0,1 & 0,1 & 0,1 & 0,1 \\
\hline Totaal vlees & 76,7 & 77,1 & 77,8 & 78,1 & 79,1 & 79,0 & 78,2 & 77,6 & 77,5 & 77,3 & 76,7 & 76,6 & 76,6 & 77,2 & 77,8
\end{tabular}

a) Op basis van karkasgewicht (gewicht met been).

Bron: CBS, berekening Wageningen Economic Research. 


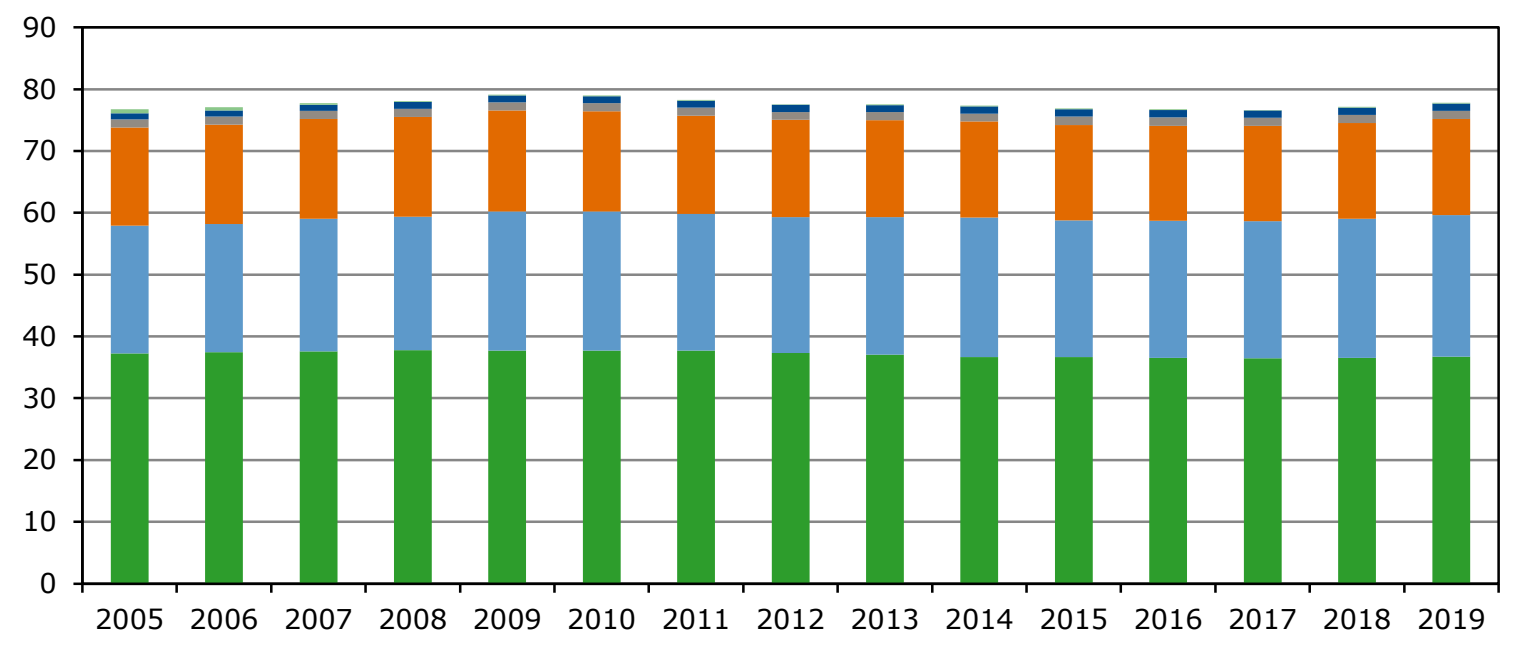

- Varkensvlees $\square$ Pluimveevlees $\square$ Rundvlees $\square$ Kalfsvlees $\square$ Schapen- en geitenvlees $\square$ Paardenvlees

Figuur 3.1 Vleesverbruik a) per hoofd van de bevolking in Nederland, 2005-2019 (kg)

a) Op basis van karkasgewicht (gewicht met been).

Bron: CBS, berekening Wageningen Economic Research. 


\section{$4 \quad$ Actuele en aanbevolen vleesconsumptie}

De in tabel 3.1 en figuur 3.1 gepresenteerde cijfers gaan over het verbruik op basis van karkasgewicht, dus vlees inclusief been, vet en zwoerd. Als vuistregel geldt dat daarvan ongeveer de helft feitelijk geconsumeerd wordt als vlees en vleeswaren. Uitgaande van deze generieke vuistregel betekent dit dat de vleesconsumptie per capita uitkomt op zo'n $39 \mathrm{~kg}$. Deze hoeveelheid vlees die we in Nederland gemiddeld per hoofd van de bevolking aten in 2019 ligt aanmerkelijk hoger dan de geadviseerde hoeveelheid volgens de Schijf van Vijf. Voor wie vlees wil eten, is de voedingsrichtlijn om wekelijks niet meer dan $500 \mathrm{gr}$ vlees en vleeswaren te eten, waarvan maximaal $300 \mathrm{gr}$ rood vlees (dit is de verzamelnaam voor vlees afkomstig van varkens, runderen, geiten en schapen). Dit betekent afgerond zo'n $70 \mathrm{gr}$ per dag en jaarlijks minder dan $26 \mathrm{~kg}$ per jaar. Het voedingsadvies ligt dus zo'n $13 \mathrm{~kg}$ lager dan we gemiddeld eten per persoon in het jaar 2019. De bij publicatie vorig jaar al van aanvang af gezaghebbende studie door de EAT-Lancet Commissie komt in het referentiedieet uit op een gemiddelde van $43 \mathrm{gr}$ vlees per dag (Willett et al., 2019: 7, 12). Met $14 \mathrm{gr}$ per dag (bandbreedte: 0-28 gr) voor rood vlees (rund, varken en lam worden genoemd) en $29 \mathrm{gr}$ per dag (bandbreedte: 0-58 gr) voor 'wit' pluimveevlees (kip en gevogelte), betekenen zulke getallen circa $100 \mathrm{gr}$ rood vlees per week en zo'n $200 \mathrm{gr}$ wit vlees per week. De jaarlijkse hoeveelheid komt daarmee nog eens zo'n $10 \mathrm{~kg}$ lager uit dan de Schijf van Vijf. Een getal rond de 15 à $16 \mathrm{~kg}$ betekent een reductie van zo'n 60\% ten opzichte van de hoeveelheid vlees die we in Nederland anno 2019 gemiddeld eten. Bovendien verandert in vergelijking met de Schijf van Vijf de verhouding van 60:40 tussen rood en wit vlees in het dieet in de EAT-Lancetstudie naar een verdeling van circa 33:67 (zie figuur 4.1).

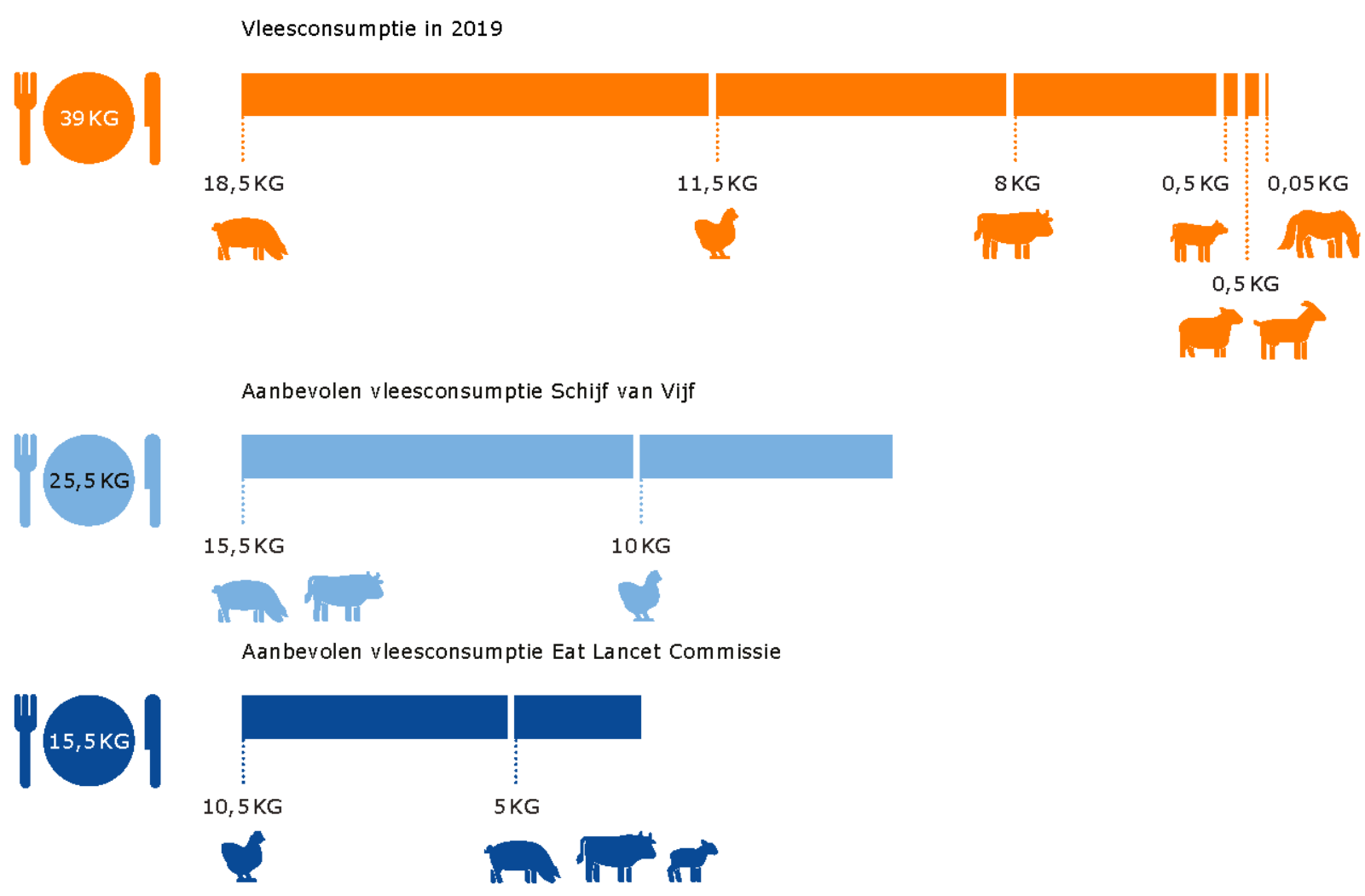

Figuur 4.1 


\section{$5 \quad$ Vlees eten buitenshuis en door buitenlandse toeristen}

$\mathrm{Na}$ de oplopende vleesconsumptie in 2018 betekenen de 2019-cijfers wederom een toename ten opzichte van 2018 met zo'n halve kilo. Om de stijgende vleesconsumptie van enige duiding te voorzien, zijn in voorgaande edities van deze nota een aantal mogelijke verklaringen behandeld. Zo wordt in Dagevos et al. (2018: 8) geopperd dat buitenhuishoudelijke consumptie in (fastfood)restaurants een factor van betekenis is in het leveren van een bijdrage aan de vleesconsumptie in Nederland. In de nota van vorig jaar (Dagevos et al., 2019: 9) wordt in het verlengde hiervan de nog iets specifiekere mogelijkheid besproken dat het buitenlandse toerisme mogelijk een rol meespeelt door een toename in het aantal (vleesrijke) horecamaaltijden dat geserveerd is aan het oplopende aantal toeristen dat Nederland bezoekt. In het onderstaande gaan we kort verder in op elk van beide veronderstellingen.

\section{Buitenhuisconsumptie in restaurants}

In een dit jaar verschenen wetenschappelijke paper wordt een vergelijking gemaakt tussen binnenhuishoudelijke vleesconsumptie en vlees eten buitenshuis (Biermann en Rau, 2020). Deze Duitse studie richt zich op de (sociale) betekenis die consumenten hechten aan het eten van vlees in de private sfeer van het eigen huis in vergelijking met de publieke omgeving van een restaurant waar men uit eten gaat. Er zijn nog nauwelijks wetenschappelijk onderbouwde antwoorden te geven op de vraag of de voedingskeuzes die mensen thuis en buitenshuis maken op elkaar lijken of juist van elkaar verschillen. Biermann en Rau vermoeden dat de gedachte dat er veel gelijkenis is - zoals wel wordt verondersteld - niet klopt. Hun verwachting is eerder dat er de nodige verschillen bestaan tussen de context van het eigen huis en de buitenhuishoudelijke context van een restaurant. De onderzoeksresultaten zijn gebaseerd op de antwoorden die 420 respondenten hebben gegeven op uiteenlopende vragen over wat ze belangrijk vinden als ze denken aan thuis eten en buitenshuis uit eten gaan.

Hoewel het de onderzoekers niet zozeer te doen is om de hoeveelheid vlees die respondenten eten in de verschillende settings, maar meer om wat hun voorkeuren zijn en welke keuzes ze maken, is een opvallend resultaat dat slechts $15 \%$ van de respondenten aangeeft thuis vaker vlees te eten dan in een restaurant, terwijl $43 \%$ aangeeft vaker vlees te eten als men uit eten gaat. Dit laatste geldt met name voor de flexitariërs onder de respondenten, ofwel voor degenen die minder vaak vlees eten. De overige $42 \%$ ziet weinig verschil in hun vleesconsumptie thuis en buitenshuis. Onder deze groep bevinden zich relatief minder flexitariërs en meer consumenten die door de onderzoekers met omnivoren worden aangeduid. Voor zowel flexitariërs als omnivoren blijkt de keuze voor vlees samen te hangen met het eten in gezelschap van anderen. Voor beide groepen geldt dat zodra er in de thuissituatie gasten aan tafel zijn de kans dat er vlees (of vis) wordt gegeten omhoogschiet. Voor buitenshuis eten geldt eveneens een sterke associatie met een keuze voor het eten van vlees. Jezelf verwennen blijkt hier een belangrijk argument. Met name voor flexitariërs geldt dat thuis koken en eten ook goed samengaat met geen of minder vlees. Maar kennelijk geldt dit minder voor de restaurantsetting, waar een meerderheid van bijna $59 \%$ van de flexitariërs $(n=87)$ vaker voor vlees kiest. Als uit eten wordt gegaan, wordt het plantaardige alternatief ook door de flexitarisch etende respondenten lang niet altijd als even aantrekkelijk beschouwd als een keuze voor vlees. Ook het gebrek aan keuze kan er debet aan zijn dat het plantaardige alternatief niet gelijkwaardig is aan het kiezen voor een vleesgerecht op de menukaart. De veronderstelling dat buitenshuis eten bevorderlijk is voor de vraag naar vlees krijgt bevestiging in deze studie van Biermann en Rau, die erop wijst dat uit eten gaan vaak een keuze voor vlees betekent. Uiteraard heeft dit mede te maken met het menu-aanbod in restaurants en met wat we als lekker en luxe, als traktatie en feestelijk zijn gaan ervaren en bestempelen. Dit alles neemt niet weg dat er ook aanwijzingen worden gevonden dat er verschillen bestaan - en aan het ontstaan zijn - voor veel consumenten tussen binnenhuishoudelijke vleesconsumptie en vlees eten buitenshuis. Het initiële idee van de onderzoekers dat mensen niet per se hetzelfde (willen) eten als thuis wanneer ze uit eten zijn, krijgt ondersteuning. Met name de in de thuissituatie vleesminderende flexitariër verlaat deze praktijk gemakkelijk zodra buiten de deur wordt gegeten. 


\section{Vleesconsumptie buitenlandse toeristen}

Het aantal buitenlandse toeristen is de afgelopen jaren gestegen. Met name gedurende de jaren tien is het aantal overnachtingen door buitenlandse toeristen voortdurend gestegen (zie Vermeulen, 2019: 210; zie onderstaande tabel 5.1). Ook de jaarcijfers voor 2019 laten een duidelijke stijging zien.

Om een idee te krijgen van de mogelijke betekenis van vleesconsumptie door buitenlandse toeristen voor de binnenlandse consumptie is via een macrobenadering een inschatting te maken. We zijn geïnteresseerd in de mogelijke toename van die consumptie op het totaal. Bij wijze van klein denkexperiment hierover stellen we ons een aantal populaire menukeuzes onder toeristen voor, zoals kipsaté, een hamburger (rundvlees) of spareribs (varkensvlees). Ervan uitgaande dat zulke menukeuzes zo'n $150 \mathrm{gr}$ vlees betekenen (in karkasgewicht is dat circa $300 \mathrm{gr}$ ) geeft dat de consumptie van vlees per maaltijd. Laten we voor de gedachtevorming aannemen dat elke overnachting betekent dat een buitenlandse toerist ook een maaltijd met vlees nuttigt die dag. Uiteraard zijn er buitenlandse toeristen die (tijdens hun verblijf in Nederland) geen vlees eten, zoals er eveneens buitenlandse gasten zullen zijn die meerdere keren vlees(waren) eten tijdens hun verblijf op Hollandse bodem. Als de genoemde portie vlees wordt vermenigvuldigd met de ruim 51 miljoen geboekte overnachtingen door buitenlandse toeristen in 2019 dan geeft dit een totaal van 15,5 miljoen $\mathrm{kg}$ vlees (karkasgewicht). Dat is 0,9 kg vlees per hoofd van bevolking in Nederland (tabel 5.1).

Tabel 5.1 Buitenlands toerisme en aandeel in vleesverbruik

\begin{tabular}{|c|c|c|c|c|}
\hline & $\begin{array}{l}\text { Totaal aantal } \\
\text { overnachtingen uit } \\
\text { het buitenland ( } \mathrm{mln} \text {.) }\end{array}$ & $\begin{array}{r}\text { Totale vleesverbruik } \\
\text { toeristen (ton) }\end{array}$ & $\begin{array}{r}\text { Per hoofd van de } \\
\text { Nederlandse } \\
\text { bevolking }(\mathbf{k g})\end{array}$ & $\begin{array}{r}\text { Bevolking } \\
\text { (mln.) }\end{array}$ \\
\hline 2013 & 31,771 & 9.531 & 0,57 & 16,780 \\
\hline 2014 & 34,424 & 10.327 & 0,61 & 16,829 \\
\hline 2016 & 39,624 & 11.887 & 0,70 & 16,979 \\
\hline 2017 & 44,169 & 13.251 & 0,78 & 17,082 \\
\hline 2018 & 47,002 & 14.101 & 0,82 & 17,181 \\
\hline 2019 & 51,750 & 15.525 & 0,90 & 17,282 \\
\hline
\end{tabular}

Bron: CBS, berekening Wageningen Economic Research.

Op basis van het gebruikte rekenvoorbeeld neemt de bijdrage van buitenlandse toeristen aan de totale vleesverbruik op Nederlands grondgebied toe. De kolom 'Per hoofd van de Nederlandse bevolking' geeft aan dat er een oplopend aandeel is van door toeristen geconsumeerd vlees op het totale vleesverbruik naar bijna een kilo per persoon, terwijl dat in 2012 ruim een pond beliep. Omdat onbekend is of het vleesconsumptiepatroon van buitenlandse toeristen veranderd is gedurende 2012-2019, is de portiegrootte van 150 gr constant gehouden.

Een blik op de cijfers in tabel 3.1 gedurende dezelfde tijdsperiode 2012-2019 leert dat dergelijke hoeveelheden het verschil kunnen maken tussen een dalende of stijgende lijn in de trend. De meer dan 20 miljoen buitenlandse gasten die in 2019 gemiddeld ruim 2,5 dag in Nederland verbleven en samen goed waren voor meer dan 51 miljoen dagen waarin ook gegeten werd, leveren in absolute zin een bescheiden bijdrage aan de totale hoeveelheid vlees die in Nederland wordt gegeten, maar in relatieve zin kan dit aandeel substantieel zijn voor het verschil tussen een dalende of stijgende beweging in de vleesverbruikscijfers.

$\mathrm{Nu}$ in 2020 toerisme en buitenhuishoudelijke consumptie stevig is teruggelopen vanwege de coronacrisis, zullen de 2020-vleesverbruikscijfers mogelijk op minder indicatieve wijze en meer 'harde' cijfermatige wijze uitsluitsel kunnen geven over het belang van toerisme en horeca voor de hoeveelheid vlees die we in Nederland eten. Door de coronapandemie is het aantal toeristen dat Nederland bezoekt drastisch teruggelopen. Vanwege coronamaatregelen hebben restaurants en andere eetgelegenheden hun deuren een periode helemaal moeten sluiten om daarna hun deuren te mogen openen voor een beperkt aantal gasten. Verwacht mag worden dat deze ontwikkelingen zich zullen tonen in de cijfers over 2020. Althans, 
het zou verbazen wanneer de terugloop in de vraag naar vlees door de impact van de coronacrisis op toerisme en horeca volledige compensatie krijgt in omzetstijging van slagers en supermarkten vanwege oplopende binnenhuishoudelijke vleesconsumptie. Mochten de gekrompen horecamogelijkheden in 2020 doorwerken in teruglopende cijfers, dan geeft dit ondersteuning aan de veronderstelling dat buitenshuis eten en buitenlands toerisme factoren zijn die bevorderlijk zijn voor het hoog houden van de vleesverbruikscijfers in Nederland. De editie van deze nota volgend jaar zal naar verwachting hier enige opheldering in kunnen verschaffen. 


\section{Literatuur en websites}

Biermann, G. en H. Rau (2020). 'The meaning of meat: (Un)sustainable eating practices at home and out of home'. In: Appetite, 153, 104730. https://doi.org/10.1016/j.appet.2020.104730

Dagevos, H., D. Verhoog, P. van Horne en R. Hoste (2018). Vleesconsumptie per hoofd van de bevolking in Nederland, 2005-2017. Wageningen: Wageningen Economic Research.

https://edepot.wur. nl/464580

Dagevos, H., D. Verhoog, P. van Horne en R. Hoste (2019). Vleesconsumptie per hoofd van de bevolking in Nederland, 2005-2018. Wageningen: Wageningen Economic Research.

https://edepot.wur.nl/499852

Verhoog, D., H. Wijsman en I. Terluin (2015). Vleesconsumptie per hoofd van de bevolking in Nederland, 2005-2014. Den Haag: LEI-Wageningen UR. http://edepot.wur.nl/359425

Vermeulen, T. (red.) (2019). Trendrapport toerisme, recreatie en vrije tijd 2019. Nieuwegein: Pleisureworld NRIT, Centraal Bureau voor de Statistiek, NBTC Holland Marketing en CELTH, Centre of Expertise Leisure, Tourism \& Hospitality. https://www.cbs.nl/nl-

nl/publicatie/2019/48/trendrapport-toerisme-recreatie-en-vrije-tijd-2019

Willett, W., J. Rockström, B. Loken, M. Springmann, T. Lang, et al. (2019). 'Food in the Anthropocene: The EAT-Lancet Commission on healthy diets from sustainable food systems'. In: The Lancet, 393(10170), 447-492. https://www.thelancet.com/commissions/EAT 
Wageningen Economic Research Postbus 29703

2502 LS Den Haag

T 0703358330

Ecommunications.ssg@wur.nl

www.wur.nl/economic-research

Wageningen Economic Research NOTA

2020-078
De missie van Wageningen University \& Research is 'To explore the potential of nature to improve the quality of life'. Binnen Wageningen University \& Research bundelen Wageningen University en gespecialiseerde onderzoeksinstituten van Stichting Wageningen Research hun krachten om bij te dragen aan de oplossing van belangrijke vragen in het domein van gezonde voeding en leefomgeving. Met ongeveer 30 vestigingen, 6.500 medewerkers ( $5.500 \mathrm{fte})$ en 12.500 studenten behoort Wageningen University \& Research wereldwijd tot de aansprekende kennisinstellingen binnen haar domein. De integrale benadering van de vraagstukken en de samenwerking tussen verschillende disciplines vormen het hart van de unieke Wageningen aanpak. 



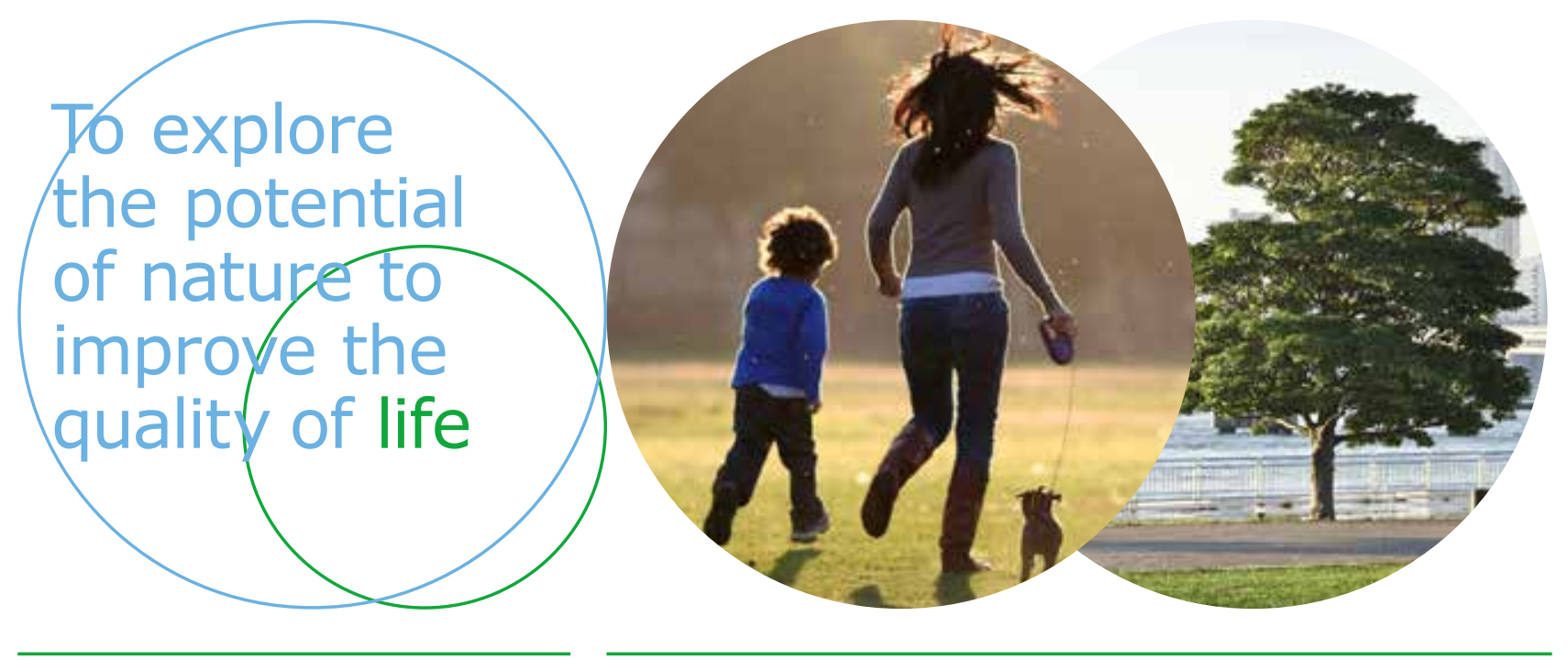

Wageningen Economic Research Postbus 29703

2502 LS Den Haag

T 0703358330

E communications.ssg@wur.nl www.wur.nl/economic-research

Nota $2020-078$
De missie van Wageningen University \& Research is 'To explore the potential of nature to improve the quality of life'. Binnen Wageningen University \& Research bundelen Wageningen University en gespecialiseerde onderzoeksinstituten van Stichting Wageningen Research hun krachten om bij te dragen aan de oplossing van belangrijke vragen in het domein van gezonde voeding en leefomgeving. Met ongeveer 30 vestigingen, 6.500 medewerkers ( $5.500 \mathrm{fte}$ ) en 12.500 studenten behoort Wageningen University \& Research wereldwijd tot de aansprekende kennisinstellingen binnen haar domein. De integrale benadering van de vraagstukken en de samenwerking tussen verschillende disciplines vormen het hart van de unieke Wageningen aanpak. 